\title{
Effect of Cyclosporin A and Zidovudine on Immune Abnormalities Observed in the Murine Acquired Immunodeficiency Syndrome
}

\author{
Andreas Cerny, Ramón Merino, Liliane Fossati, \\ Sylvie de Kossodo, Christoph Heusser, \\ Francis A. Waldvogel, Herbert C. Morse III, \\ and Shozo Izui
}

\author{
Departments of Medicine and Pathology, Hôpital Cantonal Universitaire, \\ Geneva, and Ciba Geigy, Preclinical Research, Basel, Switzerland; \\ Laboratory of Immunopathology. National Institute of Allergy and \\ Infectious Diseases, National Institutes of Health, Bethesda, Maryland
}

\begin{abstract}
Two therapeutic modalities, zidovudine (targeting retroviral replication) and cyclosporin $\mathbf{A}$ (targeting immunopathologic consequences of retroviral expression) were evaluated in a murine model of AIDS. In previous studies, cyclosporin A treatment (40 or $60 \mathrm{mg} / \mathrm{kg} / \mathrm{day}$ ) before and after infection with LP-BM5 murine leukemia viruses protected against the development of immunodeficiency disease. The present study extends these findings. First, a low dose of cyclosporin A (20 mg/kg/day) was ineffective, and treatment initiated 5 days after infection did not protect against virus-induced lymphoproliferation and hypergammaglobulinemia. Second, zidovudine added to drinking water $(0.1 \mathrm{mg}$ initiated 5 days after infection and continued for 8 weeks) was more effective than $0.2 \mathrm{mg} / \mathrm{mL}$ given day 5-12 after infection. This treatment reduced lymph node size, disease severity as determined histologically, retrovirus-induced gp 70 expression, and IgE (but not IgM and IgG) levels. Third, combined treatment had an additive, protective effect on lymphocyte proliferative capacity. This successful dual therapeutic strategy in a mouse model has potential applicability for similar approaches in treating human immunodeficiency virus infection.
\end{abstract}

The LP-BM5 murine leukemia viruses (MuLV) induce an immunodeficiency disease in susceptible murine strains [16]. The disorder has a natural history in many ways comparable to human immunodeficiency virus (HIV-l)-induced AIDS in humans and has therefore been termed murine AIDS (MAIDS) [3]. Dysfunction of $\mathrm{CD}^{+} \mathrm{T}$ cells is a key feature in both conditions and precedes a numerical reduction of this $T$ cell subset even though the LP-BM5 viruses have no selective tropism for $\mathrm{CD}^{+} \mathrm{T}$ cells [7].

Previous studies of mice with MAIDS demonstrated that interactions between $\mathrm{CD} 4^{+} \mathrm{T}$ cells and $\mathrm{B}$ cells are central to the pathogenesis of this syndrome; infected mice depleted in vivo of $\mathrm{CD}^{+} \mathrm{T}$ cells had phenotypically and functionally normal $B$ cells [8], while infected mice depleted of mature B cells had phenotypically and functionally normal $\mathrm{CD}^{+}$and $\mathrm{CD}^{+} \mathrm{T}$ cells [9]. Indirect evidence suggests that B cell-de-

Received I December 1991; revised 16 March 1992.

Presented in part: 1 th European Federation of Immunological Societies Meeting, Espoo, Finland, June 1991.

Financial support: Geigy-Jubiläums-Stiftung, Foundation for the Support of AIDS Research in Switzerland (7009 to A.C.). Swiss National Foundation for Scientific Research (31.28782.90 to S.I.), National Institutes of Health (AI-72622 to Microbiologic Associates. Bethesda [to H.C.M.]), and Servicio de Formación de Personal Investigador, Ministerio de Educación y Ciencia. Spain (to R.M.).

Reprints or correspondence (present address): Dr. Andreas Cerny, Zieglerspital. Medizinische Abteilung. Morillonstrasse 75-91, Postfach 3001 Bern, Switzerland.

The Journal of Infectious Diseases 1992;166:285-90 (c) 1992 by The University of Chicago. All rights reserved. $0022-1899 / 92 / 6602-0009 \$ 01.00$ pendent $T$ cell activation through a mechanism involving a retrovirus-associated superantigen is crucial to the development of the disease [10]. Furthermore, inappropriate regulation of lymphokine expression, including genes encoding interferon (IFN) $-\alpha,-\beta$, and $-\gamma[11]$, interleukin (IL)- 1 [12], -2 $[7,13],-4,-5,-6$, and -10 [13], and tumor necrosis factor [12], may be of importance.

We have analyzed the therapeutic effect of cyclosporin A, which interferes with crucial steps in T cell activation [14]. Treatment with cyclosporin A (40 and $60 / \mathrm{mg} / \mathrm{kg} /$ day) before and after infection with LP-BM5 MuLV significantly inhibited the development of immunologic and histopathologic changes characteristic of MAIDS [15]. This study extends our analysis by using cyclosporin $\mathrm{A}$ at lower doses either alone or combined with zidovudine, an inhibitor of retroviral reverse transcriptase [16].

\section{Materials and Methods}

Mice and viruses. Inbred female C57BL/6 (B6; $H-2^{b}$; susceptible to LP-BM5-induced disease) mice were obtained from IFFA Credo (l'Arbresle, France). Mice were injected at the age of 4 weeks intraperitoneally with $0.1 \mathrm{~mL}$ of LP-BM5 MuLV stock containing a replication-defective component as described $[2,5,6]$ and $\sim 10 \mathrm{ffu} / \mathrm{mL} \mathrm{MCF}$ (mink cell focus-inducing) virus and $10^{3.8}-10^{5} \mathrm{pfu} / \mathrm{mL}$ ectropic MuLV.

Drug treatments. Cyclosporin A was a gift of $\mathrm{J},-\mathrm{F}$. Borel (Sandoz, Basel, Switzerland). The powder was dissolved in alcohol and tween 80 , diluted with PBS, and injected daily intraperitoneally. Either 20 or $40 \mathrm{mg} / \mathrm{kg} /$ day was begun 1 day before 


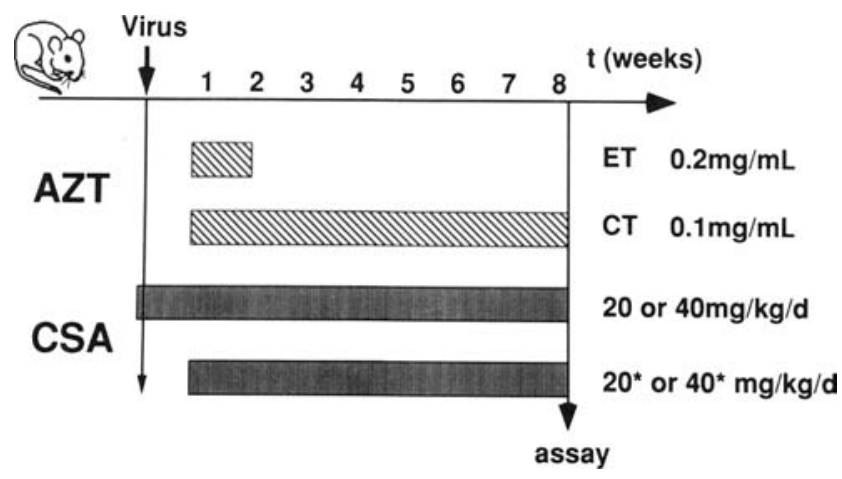

Figure 1. Experimental protocol. B6 mice were infected with LP-BM5 murine leukemia virus at 4 weeks old. Zidovudine (AZT) was added to drinking water beginning 5 days after infection, either at $0.2 \mathrm{mg} / \mathrm{mL}$ for 1 week (ET, early treatment) or at $0.1 \mathrm{mg} / \mathrm{mL}$ until end of experiment at 8 weeks (CT, continuous treatment). Cyclosporin A (CSA) was given at 20 or $40 \mathrm{mg} / \mathrm{kg} /$ day intraperitoneally; treatment was begun 1 day before infection or 5 days after (*).

infection or 5 days after infection until the end of the experiment 8 weeks later.

Zidovudine was supplied by Wellcome Research Laboratories (Beckenham, UK) and administered orally in the drinking water at a concentration of $0.2 \mathrm{mg} / \mathrm{mL}$ days $5-12$ after infection (early treatment) or at $0.1 \mathrm{mg} / \mathrm{mL}$ from day 5 until the end of the experiment (continuous treatment). The doses used did not induce toxicity, and mouse weight, hematocrit, and histology of major organs remained unaffected.

Treatment regimens are shown in figure 1. Two independent sets of experiments were done, and representative results from one set are reported.

Histopathology. Samples of all major organs were obtained at autopsy, and histologic sections were stained with hematoxylin-eosin. The histopathologic staging was done by an immunopathologist blinded for the experimental protocol according to criteria previously described [3]. Briefly, splenic histology is defined as reactive $(R)$ by hyperplasia of periarterial lymphoid sheaths and follicles due to accumulation of immunoblasts and plasmocytoid cells as well as plasma cells without distortion of their round shape. Stage I is distinguished by an eccentric hyperplasia of the periarterial sheaths with hourglass shapes. The mantle zone is still intact and there is no compression of the red pulp. In stage II, there is extensive enlargement of periarterial sheaths, loss of the mantle zone, and compression of the red pulp. Lymphoid masses are still separated by stretches of red pulp. In stage III, nodular confluent masses of lymphoid tissue are associated with obliteration of the red pulp.

Serology. Serum immunoglobulin levels were determined by ELISA with immunoglobulin class- and subclass-specific reagents and standards as detailed elsewhere [17, 18]. The determination of serum gp70 levels has been described [19].

Proliferative responses. Proliferative responses to mitogens were induced in cultures of spleen cells $\left(2 \times 10^{5} /\right.$ well $)$ in $0.2 \mathrm{~mL}$ of Dulbecco's modified Eagle medium (DMEM) supplemented with $10 \%$ fetal calf serum, $2^{\prime}$-mercaptoethanol, and antibiotics in 96-well microtiter plates (Costar, Cambridge, MA). Concanavalin A ( $2 \mu \mathrm{g} / \mathrm{mL}$; Pharmacia, Uppsala, Sweden) and lipopolysaccharide (20 $\mu \mathrm{g} / \mathrm{mL}$; Escherichia coli O55:B5; Difco, Detroit) were added at the beginning and cultures were pulsed overnight with $\left[{ }^{3} \mathrm{H}\right]$ thymidine before harvesting after $48 \mathrm{~h}$.

Statistical analysis. The Wilcoxon signed rank test was used.

\section{Results}

Effect of zidovudine and cyclosporin A treatment on development of lymphadenopathy and histopathologic changes. Infection with the LP-BM5 viruses is associated with subsequent lymphoproliferation due to polyclonal $\mathrm{T}$ and $\mathrm{B}$ cell expansion. Disease progression is paralleled by typical changes in splenic histomorphology.

Table 1 summarizes the effect of cyclosporin $A$ and zidovudine on lymphoid organ size and on histopathology. The higher dose of cyclosporin A ( $40 \mathrm{mg} / \mathrm{kg} /$ day) was effective in reducing lymph node size, but only when treatment was initiated before infection $(P<.05)$. Treatment with zidovudine was more efficacious when given continuously than when given during days 5-12 only. Combining zidovudine and cyclosporin A resulted in a further significant reduction of lymph node size compared with treatment with either continuous zidovudine $(P<.05)$ or cyclosporin $\mathrm{A}(P<.05)$ alone.

Disease severity, quantitated by morphologic criteria, was attenuated by cyclosporin $\mathrm{A}$ treatment initiated before and continued after infection. Infected mice treated with cyclosporin $\mathrm{A}$ at $40 \mathrm{mg} / \mathrm{kg} /$ day showed mostly reactive changes irrespective of whether zidovudine was coadministered. $\mathrm{Zi}$ dovudine alone (continuous treatment), however, did attenuate histologic disease severity. Cyclosporin $A$ initiated 5 days after infection reduced disease severity to a lesser but statistically significant degree $(P<.05)$.

Effect of zidovudine and cyclosporin A treatment on development of hypergammaglobulinemia. LP-BM5 infection induces rapid and sustained polyclonal $B$ cell activation resulting in hypergammaglobulinemia $[20,21]$. Treatment of infected mice with cyclosporin A resulted in a dose-dependent reduction of all immunoglobulin isotypes tested when treatment was initiated before infection (table 1). No significant effect was observed when the drug was started 5 days after infection. Zidovudine treatment did not significantly affect hypergammaglobulinemia of the $\operatorname{IgM}$ and $\operatorname{IgG}$ isotype observed in infected mice, nor did it add to the effect of cyclosporin A when the drugs were used together. However, IgE levels were reduced by continuous zidovudine treatment compared with those seen in infected untreated mice $(P<.05)$.

Effect of zidovudine and cyclosporin $A$ treatment on serum gp70 expression. Serum gp 70 levels can be used as a means 
Table 1. Effect of zidovudine and cyclosporin A treatment on development of lymphadenopathy, histopathologic alterations, and hypergammaglobulinemia.

\begin{tabular}{|c|c|c|c|c|c|}
\hline \multirow[b]{2}{*}{ Treatment regimen, infection } & \multirow[b]{2}{*}{$\begin{array}{l}\text { Cervical lymph } \\
\text { node weight, mg }\end{array}$} & \multirow{2}{*}{$\begin{array}{l}\text { Histopathologic } \\
\text { stage }\end{array}$} & \multicolumn{3}{|c|}{ Serum immunoglobulin levels } \\
\hline & & & $\operatorname{IgM}, \mu \mathrm{g} / \mathrm{mL}$ & $\mathrm{IgG}, \mathrm{mg} / \mathrm{mL}$ & $\mathrm{IgE}, \mathrm{ng} / \mathrm{mL}$ \\
\hline \multicolumn{6}{|l|}{ None } \\
\hline Uninfected & $17(6)$ & ND & $296(224)$ & $7.9(2.6)$ & $<20$ \\
\hline Infected & $224(82)$ & II (I-III) & $1556(297)$ & $32.9(3.5)$ & $572(475)$ \\
\hline Uninfected & $12(4)$ & ND & $260(187)$ & $8.6(1.9)$ & ND \\
\hline Infected & $220(101)$ & ND & $1295(612)$ & $35.7(3.1)$ & ND \\
\hline \multicolumn{6}{|l|}{$40 \mathrm{mg} / \mathrm{kg} /$ day } \\
\hline Uninfected & $10(0)$ & ND & $464(193)$ & $9.6(2.3)$ & $43(17)$ \\
\hline Infected & $90(14)$ & $R(N-R)$ & $452(139)$ & $19.9(3.8)$ & $136(145)$ \\
\hline \multicolumn{6}{|l|}{ Cyclosporin $\mathrm{A}$ after infection } \\
\hline Infected & $213(106)$ & II (I-II) & $1302(252)$ & $28.6(3.2)$ & $875(322)$ \\
\hline \multicolumn{6}{|l|}{ Zidovudine, continuous treatment } \\
\hline Uninfected & $10(0)$ & ND & $103(25)$ & $5.4(1.7)$ & ND \\
\hline Infected & $130(49)$ & $\mathrm{I}(\mathrm{R}-\mathrm{II})$ & $1117(304)$ & $30.1(3.9)$ & $161(81)$ \\
\hline \multicolumn{6}{|c|}{ Cyclosporin A. $40 \mathrm{mg} / \mathrm{kg} /$ day, plus zidovudine } \\
\hline Early treatment, infected & $67(28)$ & $\mathrm{R}(\mathrm{R})$ & $303(63)$ & $15.2(2.8)$ & $21(3)$ \\
\hline Continuous treatment, infected & $66(34)$ & $\mathrm{R}(\mathrm{N}-\mathrm{R})$ & $856(312)$ & $21.6(6.6)$ & $94(81)$ \\
\hline
\end{tabular}

NOTE. Intraperitoneal treatment with cyclosporin A (groups of 6 B6 mice) was begun at agc 4 weeks, 1 day before or 5 days after infection with LP-BM 5 murine leukemia viruses, and continued for 8 weeks. Zidovudine was added to drinking water $5-12$ days after infection at $0.2 \mathrm{mg} / \mathrm{mL}$ (early treatment) or from day 5 after infection for 8 weeks at $0.1 \mathrm{mg} / \mathrm{mL}$ (continuous treatment). Histopathologic staging, given as median (range): N, normal; R, reactive; I-III, discrete and progressive stages of disease severity. Other data are mean (SD). ND = not done.

to quantify retroviral expression, as shown previously for LPBM5 MuLV [15]. Figure 2 shows increased gp 70 levels for infected compared with uninfected mice. These increases were not affected by treatment with cyclosporin $\mathrm{A}$ alone. However, chronic administration of zidovudine lowered gp 70 expression. When infected mice were compared, differences between those untreated and continuously zidovudine treated were significant $(P<.03)$, as were differences between mice treated with cyclosporin $A(40 \mathrm{mg} / \mathrm{kg} /$ day) and with the combination of cyclosporin $A(40 \mathrm{mg} / \mathrm{kg} /$ day) and zidovudine ( $P<.03$ for early or continuous treatment). In other words, zidovudine (early treatment) combined with cyclosporin A was more effective than zidovudine (early treatment) alone or cyclosporin $\mathrm{A}$ alone.

Effect of zidovudine and cyclosporin A treatment on mitogen-induced proliferative responses. Eight weeks after infection, spleen cells were assessed for their capacity to respond to stimulation with the mitogens concanavalin $\mathrm{A}$ and lipopolysaccharide (table 2). Proliferative responses were almost totally abrogated in spleen cells from infected untreated mice compared with those from uninfected control mice, changes characteristic of MAIDS [1, 7, 20]. Treatment with cyclosporin A or zidovudine alone did not beneficially influence unresponsiveness of splenocytes, as previously reported, reflecting a more advanced stage of disease progression in the present study [15]. Combining both drugs, however, led to a significant increase in proliferative responses irrespective of whether zidovudine was given as early or continuous treatment $(P<.05)$.

\section{Discussion}

Therapeutic strategies are generally designed to interfere with crucial steps in the pathogenetic sequence of a disease process. According to our working hypothesis, LP-BM5 MuLV-induced immunodeficiency can be viewed as a retrovirus-triggered superantigen-driven polyclonal stimulation of the immune system followed by exhaustion of immune function [10]. In spite of major differences in viral tropism and replication between MAIDS and AIDS, recent indirect evidence underlines a possible pathogenic role for a retrovirus-encoded superantigen in AIDS [22]. Others consider the disease a primary neoplasia with an acquired immunodeficiency syndrome as a paraneoplastic syndrome [23]. 


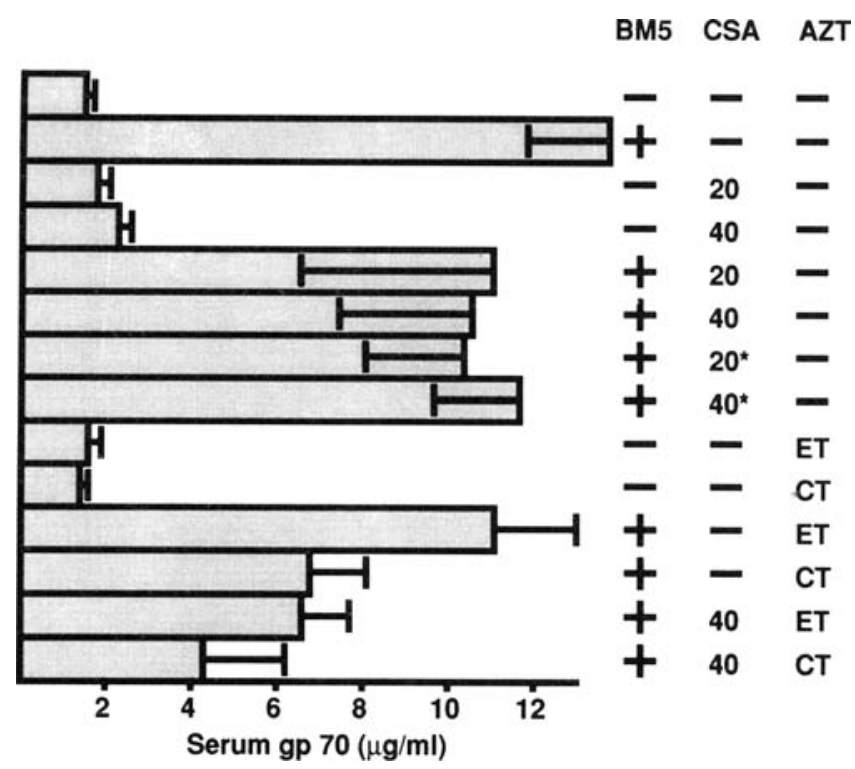

Figure 2. Effect of treatment with cyclosporine A (CSA) and zidovudine (AZT) on serum gp70 levels in LP-BM5-infected and uninfected $B 6$ mice. gp 70 levels of sera obtained after 8 weeks from 6 mice per group were determined by ELISA; results are means \pm SDs. Treatment regimens are explained in legend to figure 1.

Two therapeutic modalities, zidovudine (targeted at retroviral replication) and cyclosporin A (aimed at the immunopathologic consequences of virus expression), were evaluated in this study,

The effect of cyclosporin A on MAIDS is dose dependent. A dose of 40 or $60 \mathrm{mg} / \mathrm{kg} /$ day is necessary to suppress the rate at which disease develops; $20 \mathrm{mg} / \mathrm{kg} /$ day is not effective. Results obtained in other studies using cyclosporin $\mathrm{A}$ in vivo suggest that doses in the range of $15-30 \mathrm{mg} / \mathrm{kg}$ abrogate selfIa-restricted $T$ helper function and that higher doses are required to suppress other $T$ cell functions [24]. Treatment with cyclosporin A has to be initiated very early to influence the disease process; administration before viral infection protects mice against MAIDS, whereas a delay of 5 days renders the disease resistant to the action of cyclosporin $A$ used at 40 $\mathrm{mg} / \mathrm{kg} /$ day. This was not because of interference with helper retrovirus expression, since cyclosporin A-treated infected mice had similar levels of serum gp70, as shown here, and LP-BM5 ecotropic MuLV, as reported previously [15].

Although the molecular mechanism of cyclosporin A action is still incompletely understood, its main mode of action both in vitro and in vivo is interference with lymphokine expression during $T$ cell activation [14, 24-26]. Recent studies of cytokine production in MAIDS suggest at least two distinct phases of the disorder [13]. At I week after infection there is a burst of spontaneous proliferation and moderate- to high-level expression of IL-2, $-4,-5$, and -10 and IFN- $\gamma$ by spleen cells, a pattern consistent with activation of Th0 or a mixture of Th 1 and Th2 helper cells. However, at 2 weeks after infection and thereafter, cytokine expression by spleen was seen only after stimulation of cells with concanavalin A. and the pattern of expression was that of Th2 cells only (IL4 , IL-10). It is most likely the very early process of virus-dependent $T$ cell activation and cytokine expression that is crucially interfered with by treatment with cyclosporin A at the time of infection. Treatment beginning at later times might be expected to be less effective, as Th2 cells are 10-fold more resistant to the effects of cyclosporin $A$ than are Thl cells [27].

Hypergammaglobulinemia encompassing IgM, IgG (all subclasses), and IgE reflects activation of both Th 1 and Th2. The effect of cyclosporin A on hypergammaglobulinemia was not biased towards a particular isotype, suggesting impediment of both $\mathrm{T}$ helper pathways. This is in accord with in vitro and in vivo studies in which cyclosporin $\mathrm{A}$ affected expression of lymphokines belonging to both Th subsets, although, as noted above, Th2 cells are more resistant to the effects of cyclosporin A than are Th1 cells $[24,26,27]$.

Zidovudine has previously been used alone or combined with other nucleoside inhibitors in the LP-BM5 mouse model [28-31]. Several groups reported an effect of oral zidovudine on the development of immune abnormalities; one used a higher dose $(1 \mathrm{mg} / \mathrm{mL})$ [29], one initiated the treatment on the day of viral infection and used a lower dose ( 30 $\mathrm{mg} / \mathrm{kg} /$ day) [30], and another began $24 \mathrm{~h}$ after infection and used low doses $(0.25$ and $0.1 \mathrm{mg} / \mathrm{mL})$ [28]. The dose used here, $0.1 \mathrm{mg} / \mathrm{mL}$ corresponds to $\sim 25 \mathrm{mg} / \mathrm{kg} /$ day and was not toxic, even when given for prolonged periods of time, as

Table 2. Effect of zidovudine and cyclosporin A treatment on mitogen-induced proliferative responses of spleen cells in murine AIDS.

\begin{tabular}{lcc}
\hline Treatment regimen, infection & Lipopolysaccharide & Concanavalin A \\
\hline None & & \\
$\quad$ Uninfected & $103(19)$ & $106(22)$ \\
$\quad$ Infected & $6(4)$ & $2(2)$ \\
$\begin{array}{l}\text { Cyclosporin A, } 40 \mathrm{mg} / \mathrm{kg} / \text { day } \\
\text { Uninfected }\end{array}$ & $95(24)$ & $57(29)$ \\
$\quad$ Infected & $9(2)$ & $5(4)$ \\
Zidovudine, early treatment & $93(11)$ & $97(23)$ \\
$\quad$ Uninfected & $6(2)$ & $4(2)$ \\
$\quad$ Infected & $78(15)$ & $118(27)$ \\
Zidovudine. continuous treatment & $9(3)$ & $3(2)$ \\
$\quad$ Uninfected & & \\
$\quad$ Infected & $32(14)$ & $17(3)$ \\
Cyclosporin A plus zidovudine & $18(21)$ & $14(7)$ \\
$\quad$ Early treatment, infected & Continuous treatment, infected & \\
\hline
\end{tabular}

NOTE. Treatment regimens are explained in footnote to table 1. Data are mean (SD) $\Delta \mathrm{cpm} \times 1000 . \Delta \mathrm{cpm}=\mathrm{cpm}$ of thymidine incorporation of mitogen-containing cultures $-\mathrm{cpm}$ of unstimulated cultures. 
in these or other previously reported studies [28]. Low-dose zidovudine treatment of an established HIV infection is the clinical setting that we tried to mimic in our study design. We found zidovudine given continuously effectively reduced gp70 expression and, in addition, inhibited the development of lymphadenopathy and attenuated histopathologic signs of disease progression. No significant effect on hypergammaglobulinemia, except IgE, was observed. There was an additive effect when both zidovudine and cyclosporin A were used in preserving mitogen responsiveness of splenic lymphocytes.

Further studies are required before cyclosporin $\mathrm{A}$ can be considered as a candidate drug for the treatment of HIV-infected humans. A preliminary study of 11 patients with advanced HIV disease treated with a short course of cyclosporin A failed to show a beneficial effect on CD4 cell counts [32]. A recent report of $88 \mathrm{HIV}$-infected patients with solid organ transplants, most of whom were treated with immunosuppressants including cyclosporin $\mathrm{A}$, found no effect, either beneficial or harmful, of cyclosporin A on the course of infection with HIV [33].

This study presents a successful attempt to develop a dual therapeutic strategy combining antiviral (zidovudine) and immunomodulatory (cyclosporin A) drugs in a mouse model of AIDS that will potentially form the basis for designing similar approaches for humans infected with HIV.

\section{Acknowledgment}

We thank Christoph Müller for analyses of spleen sections.

\section{References}

1. Mosier DE, Yetter RA, Morse HC III. Retroviral induction of acute lymphoproliferative disease and profound immunosuppression in adult C57BL/6 mice. J Exp Med 1985;161:766-84.

2. Chattopadhyay SK, Morse HC III. Makino M, Ruscetti SK, Hartley $J W$. A defective virus is associated with induction of a murine retrovirus-induced immunodeficiency syndrome, MAIDS. Proc Natl Acad Sci USA 1989;86:3862-6.

3. Hartley JW, Fredrickson TN, Yetter RA, Makino M, Morse HC III. Retrovirus induced murine acquired immunodeficiency syndrome: natural history of infection and differing susceptibility of inbred mouse strains. J Virol 1989;64:1223-3!.

4. Makino M. Morse HC III, Fredrickson TN. Hartley JW. H-2 associated and background genes influence the development of a murine retrovirus-induced immunodeficiency syndrome. J lmmunol 1990;144: 4347-55.

5. Aziz DC. Hanna Z, Jolicoeur P. Severe immunodeficiency induced by a defective murine leukemia virus. Nature 1989:338:505-8.

6. Huang M, Jolicoeur P. Characterization of the gag/fusion protein encoded by the defective Duplan retrovirus inducing murine acquired immunodeficiency syndrome. J Virol 1990;64:5764-72.

7. Morse HC III, Yetter RA, Via CS, et al. Functional and phenotypic alterations in $T$ cell subsets during the course of MAIDS, a murine retrovirus induced immunodeficiency syndrome. J Immunol 1989; 143:844-50.

8. Yetter RA, Buller RML, Lee JS, et al. CD4 T cells are required for development of a murine retrovirus induced immunodeficiency syndrome (MAIDS). J Exp Med 1988;168:623-35.

9. Cerny A, Hügin AW, Hardy RR, et al. B cells are required for induction of $\mathrm{T}$ cell abnormalities in a murine retrovirus-induced immunodeficiency syndrome. J Exp Med 1990;171:315-20.

10. Hügin AW, Vacchio MS, Morse HC III. A virus-encoded "superantigen" in a retrovirus-induced immunodeficiency syndrome of mice. Science 1991;252:424-7.

11. Pitha PM, Biegel D, Yetter RA, Morse HC III. Abnormal regulation of IFN-alpha, -beta and -gamma expression in MAIDS, a murine retrovirus induced immunodeficiency syndrome. J Immunol 1988;141: 3611-6.

12. Cheung SC, Chattopadhyay SK, Morse HC III, Pitha PM. Expression of defective virus and cytokine genes in murine AIDS. J Virol $1991 ; 65: 823-8$.

13. Gazzinelli RT. Makino M, Chattopadhyay SK, et al. $\mathrm{CD}^{+}$subset regulation in viral infection: preferential activation of Th2 cells during progression of retrovirus-induced immunodeficiency in mice. J Immunol 1992;148:182-8.

14. Shevach EM. The effects of cyclosporin $A$ on the immune system. Annu Rev Immunol 1985;3:397-423.

15. Cerny A, Merino R, Makino M, Waldvogel FA, Morse HC III, Izui S. Protective effect of cyclosporin $A$ on immune abnormalities observed in the murine acquired immunodeficiency syndrome. Eur J Immunol 1991:21:1747-50

16. Mitsuya H. Weinhold KJ, Furman PA, et al. 3'-azido-3'-deoxythymidine (BW A509U), an antiviral agant that inhibits the infectivity and cytopathic effect of human T-lymphotropic virus type III/ lymphadenopathy-associated virus in vitro. Proc Natl Acad Sci USA 1985;71:4980-5.

17. Luzui S, Merino J, Engers H, lzui S, Lambert PH. Autoimmunity after induction of neonatal tolerance to alloantigens: role of $\mathrm{B}$ cell chimerism and $\mathrm{F} 1$ donor $B$ cell activation. J Immunol 1986;136:4420-6.

18. Blaser $\mathrm{K}$, Heusser $\mathrm{CH}$. Regulatory effects of isologous anti-idiotypic antibodies on the formation of different immunoglobulin classes in the immune response to phosphorylcholine in BALB/c mice. Eur $\mathrm{J}$ Immunol 1984;14:93-8.

19. Izui S, Masuda K, Yoshida H. Acute SLE in FI hybrids between SB/Le and NZW mice: prominently enhanced formation of $\mathrm{gp}^{70}$ immune complexes by a $Y$ chromosome-associated factor from SB/Le mice. J Immunol 1984;132:701-4.

20. Legrand E, Dalcusi R. Duplan JF. Characteristics of the populations involved in extra-thymic lymphosarcoma induced in C57BL/6 mice by RadLV-Rs. Leuk Res 1981:5:223-33.

21. Klinman DM, Morse HC III. Characteristics of B cell proliferation and activation in murine AIDS. J Immunol 1989;142:1144-9.

22. Imberti L. Sottini A, Bettinardi A, Puoti M. Primi D. Selective depletion in HIV infection of cells that bear specific $T$ cell receptor $V_{B}$ sequences. Science 1991;254:860-2.

23. Simard C. Jolicoeur $P$. The effect of anti-neoplastic drugs on murine acquired immunodeficiency syndrome. Science 1991;251:305-8.

24. Fukuzawa M, Shearer GM. Effect of cyclosporin A on T cell immunity. I. Dose-dependent suppression of different murine $T$ helper cell pathways. Eur J Immunol 1989;19:49-56.

25. Flanagan WM, Corthésy B, Bram RJ, Crabtree GR. Nuclear association of a T-cell transcription factor blocked by FK-506 and cyclosporin A. Nature 1991;352:803-7.

26. Granelli-Piperino A. Lymphokine gene expression in vivo is inhibited by cyclosporin A. J Exp Med 1990;171:533-44. 
27. Gajewski TF, Schell SR, Fitch FW. Evidence implicating utilization of different $T$ cell receptor-associated signaling pathways by $T h \mathrm{I}$ and Th2 clones. J Immunol 1990; 144:4110-4.

28. Basham T, Rios CD, Holdener T, Merigan TC. Zidovudine (AZT) reduces virus titer, retards immune dysfunction, and prolongs survival in the LP-BM5 murine induced immunodeficiency model. J Infect Dis 1990; 161:1006-9.

29. Ohnota H, Okada Y, Ushijima H, Kitamura T, Komuro K, Mizouchi T. 3'-azido-3'-deoxythymidine prevents induction of murine acquired immunodeficiency syndrome in C57BL/10 mice infected with LPBM5 murine leukemia viruses, a possible animal model for antiretroviral drug screening. Antimicrob Agents Chemother 1990;34:605-9.

30. Gangemi DJ, Cozens RM, De Clercq E, Balzarini J, Hochkeppel HK. 9-(2-phosphonylmethoxyethyl) adenine in the treatment of murine acquired immunodeficiency disease and opportunistic herpes simplex virus infections. Antimicrob Agents Chemother 1989;33: $1864-$ 8.

31. Basham T, Holdener T, Merigan T. Intermittent, alternating, and concurrent regimens of zidovudine and $2^{\prime}-3^{\prime}$ dideoxycytidine in the LPBM5 murine induced immunodeficiency model. I Infect Dis $1991 ; 163: 869-72$.

32. Leport C, Matheron S, Martin S, et al. Effet de la ciclosporine sur lc nombre des lymphocytes circulants et des sous-populations lymphocytaires au cours du SIDA. Presse Med 1986;15:2118-9.

33. Erice A, Rhame FS, Heussner RC, Dunn DL. Balfour HH Jr. Human immunodeficiency virus infection in patients with solid organ transplants: report of five cases and review. Rev Infect Dis 1991;13:53747. 